\title{
GCU
}

Glasgow Caledonian

University

University for the Common Good

\section{Gypenosides protect retinal pigment epithelium cells from oxidative stress}

Alhasani, Reem Hasaballah; Biswas, Lincoln; Tohari, Ali Mohammad; Zhou, Xinzhi; Reilly, James; He, Jian-Feng; Shu, Xinhua

Published in:

Food and Chemical Toxicology

DOI:

10.1016/j.fct.2017.12.037

Publication date:

2018

Document Version

Author accepted manuscript

Link to publication in ResearchOnline

Citation for published version (Harvard):

Alhasani, RH, Biswas, L, Tohari, AM, Zhou, X, Reilly, J, He, J-F \& Shu, X 2018, 'Gypenosides protect retinal pigment epithelium cells from oxidative stress', Food and Chemical Toxicology, vol. 112, pp. 76-85.

https://doi.org/10.1016/j.fct.2017.12.037

\section{General rights}

Copyright and moral rights for the publications made accessible in the public portal are retained by the authors and/or other copyright owners and it is a condition of accessing publications that users recognise and abide by the legal requirements associated with these rights.

Take down policy

If you believe that this document breaches copyright please view our takedown policy at https://edshare.gcu.ac.uk/id/eprint/5179 for details of how to contact us. 
Gypenosides protect retinal pigment epithelium cells from oxidative stress

Reem Hasaballah Alhasani ${ }^{1}$, Lincoln Biswas ${ }^{1}$, Ali Mohammed Tohari ${ }^{1}$, Xinzhi Zhou ${ }^{1}$, James Reilly ${ }^{1}$, Jian-Feng $\mathrm{He}^{2}$, Xinhua Shu ${ }^{1,{ }^{*}}$

1. Department of Life Sciences, Glasgow Caledonian University, Glasgow G4 0BA, UK

2. Department of Ophthalmology, the First Affiliated Hospital of Guangxi Medical University, Nanning 530021, China

* Corresponding author Xinhua Shu, Email: Xinhua.Shu@gcu.ac.uk 


\section{Abstract}

Oxidative stress plays a critical role in the pathogenesis of retinal degeneration. Gypenosides are the major functional components isolated from Gynostemma pentaphyllum. They have been shown to protect against oxidative stress and inflammation and have also demonstrated a protective effect on experimental optic neuritis. In order to determine the protective properties of gypenosides against oxidative stress in human retinal pigment epithelium (RPE) cells, ARPE-19 cells were treated with $\mathrm{H}_{2} \mathrm{O}_{2}$ or $\mathrm{H}_{2} \mathrm{O}_{2}$ plus gypenosides for $24 \mathrm{~h}$. ARPE-19 cells co-treated with gypenosides had significantly increased cell viability and decreased cell death rate when compared to cells treated with $\mathrm{H}_{2} \mathrm{O}_{2}$ alone. The level of $\mathrm{GSH}$, the activities of SOD and catalase, and the expression of NRF2 and antioxidant genes were notably decreased, while there were marked increases in ROS, MDA and proinflammatory cytokines in ARPE-19 cells exposed to $\mathrm{H}_{2} \mathrm{O}_{2}$; co-treatment with gypenosides significantly counteract these changes. Our study suggests that gypenosides protect RPE cells from oxidative damage and offer therapeutic potential for the treatment of retinal degeneration.

Keywords Gypenosides, oxidative stress, inflammation, cell death, ARPE-19 


\section{Introduction}

Oxidative stress is the term given to an imbalance between production of reactive oxygen species (ROS) and the removal of ROS by the oxidant scavenging defence system. Increased ROS production can cause damage to nucleic acids, lipids and proteins, and has been implicated in ageing and age-related neurodegenerative diseases (Danielson and Andersen, 2008; Kujoth et al., 2005; Moreira et al., 2008). The human retina is a part of the central nervous system and is responsible for visual function. The retina consists of a pigmented monolayer of cells (retinal pigment epithelium) and a neuroretina, comprising different types of neurons including the photoreceptor cells. The retina has the highest oxygen consumption rate in the human body, which results in an excess of ROS production ( $\mathrm{Yu}$ and Cringle, 2005). Continual exposure to light also increases the production of ROS in the retina. Photoreceptor cells become particularly susceptible to oxidative stress when under constant intrinsic and environmental challenges. Oxidative stress has been suggested to play an important role in the pathogenesis of retinal degeneration, including diabetic retinopathy, age related macular degeneration and retinitis pigmentosa (Kowluru and Mishra, 2015; Punzo et al., 2012; Shaw et al., 2016; Zhang et al., 2017).

The retinal pigment epithelium (RPE) is a monolayer of highly polarized epithelial cells whose apical membrane faces the photoreceptor outer segments and whose basolateral membrane faces Bruch's membrane. RPE cells play a critical role in maintaining health and function both of photoreceptors and choroidal capillaries (Strauss, 2005). RPE cells provide nutrition for photoreceptors and help to renew the outer segments. They also secrete a variety of growth factors for the maintenance of structural integrity both of photoreceptors and the choriocapillaris. As a part of the 
retina/blood barrier, RPE cells selectively deliver or remove metabolites and molecules to and from the photoreceptors and the choriocapillaris. Many retinal degenerative diseases are linked to dysfunction of RPE cells.

Gnostemma pentaphylum Makino has been widely used as a traditional Chinese medicine for centuries (Razmovski-Naumovski et al., 2005). In China it has been prescribed for patients with heart palpitation, chronic bronchitis, fatigue syndrome and cough. Gypenosides (Gyp) are the predominant functional component of $G$. pentaphyllum (Cui et al., 1999). Gyp have shown anti-inflammatory (Aktan et al., 2003; Cai et al., 2016; Huang et al., 2006; Wan and Zhao, 2017; Xie et al., 2012; Yu et al., 2016a), anti-oxidative (Shang et al., 2006; Wang et al., 2010; Yu et al., 2016a; Zhang et al., 2011; Zhao et al., 2014), anti-hyperlipidemic (Gou et al., 2016; Li et al., 2017; Megalli et al., 2005; Qin et al., 2012; Yang et al., 2013), anti-diabetic (He et al., 2015) and anti-tumour activities (Kong et al., 2015; Yan et al., 2014). Gyp have also demonstrated protective effects in the treatment of neurodegenerative diseases, such as Parkinson's disease (Choi et al., 2010; Wang et al., 2017). Recent studies reported that Gyp demonstrated protective effects in experimental optic neuritis (Li et al., 2014; Zhang et al., 2017). However, studies on Gyp in retinal degeneration are lacking, therefore it is of benefit to evaluate the therapeutic potential of Gyp for retinal diseases.

In the current study, we evaluated the protective effects of Gyp against $\mathrm{H}_{2} \mathrm{O}_{2}$ induced oxidative stress in vitro in the RPE cells.

\section{Materials and methods}

\subsection{Cell culture}


Human retinal pigment epithelium ARPE-19 cells (ATCC ${ }^{\circ}$ CRL-2302 ${ }^{\mathrm{TM}}$ ) were grown in Dulbecco's Modified Eagle Medium (DMEM/F12, Lonza, UK) supplemented with $10 \%$ fetal bovine serum, $100 \mathrm{mg} / \mathrm{mL}$ streptomycin, 100 units $/ \mathrm{mL}$ penicillin (Lonza, UK) and $0.26 \%$ sodium bicarbonate (Sigma).

\subsection{Cell viability}

ARPE-19 cells were seeded at a density of 80,000 cells per well in 48 -well plates (Greiner Bio One, UK) in DMEM/F12 medium and cultured in a $5 \% \mathrm{CO}_{2}$ incubator at $37^{\circ} \mathrm{C}$ for 24 hours. Confluent cells were treated with $\mathrm{H}_{2} \mathrm{O}_{2}$ and/or gypenosides (Gyp, purchased from Xi'an Jiatian Biotech Co. Ltd, China, purity 98\%) at different concentrations $\left(\mathrm{H}_{2} \mathrm{O}_{2}: 50,100,250,500,750\right.$ and $1000 \mu \mathrm{M}$; Gyp: 1, 2.5, 5, 7.5 and $10 \mu \mathrm{g} / \mathrm{ml}$ ) for 24 hours. The cell viability was assessed using an MTT assay $(0.4 \mathrm{mg} / \mathrm{ml}, 200 \mu \mathrm{l} /$ well) (Sigma, UK) according to the protocols. The absorbance was measured at $570 \mathrm{~nm}$ in a microplate spectrophotometer Epoch reader (Biotech, UK). The percentage of viable cells was determined using the following formula: $\%$ of viable cells $=[$ (absorbance of untreated cells-absorbance of treated cells)/absorbance of untreated cells] $\times 100$. All the experiments were performed in triplicate under the same conditions.

\subsection{Detection of cell death}

DeadEnd $^{\mathrm{TM}}$ fluorometric TUNEL assay kit (Promega) was used to detect cell death following the manufacturer's instructions. Briefly, treated and control cells were fixed with $4 \%$ PFA for 20 min at $4^{\circ} \mathrm{C}$, washed with PBS and permeabilised for 5 min with $0.2 \%$ Triton $\mathrm{X}-100$ in PBS. Cells were labelled with rTDT reaction mix for one hour at $37^{\circ} \mathrm{C}$ and the reaction was stopped with $2 \times$ SSC. Cells were washed with PBS and incubated with DAPI (Cat. Number D9542, Sigma). After washing with PBS, cells were mounted with FluorSave ${ }^{\mathrm{TM}}$ reagent (Merck Millipore, Cat. number 345789). 
Images were captured using ZEISS LSM 800 confocal microscopy. Cell death was quantified by counting the number of TUNEL positive cells in 300 cells from three individual samples (100 cells in each sample).

\subsection{Measurement of reactive oxygen species (ROS)}

ARPE-19 cells were seeded in clear-bottomed black 96-well (30,000cells/well) tissue culture plates (Greiner Bio One, UK) and cultured for 24 h. ARPE-19 cells were treated with $\mathrm{H}_{2} \mathrm{O}_{2}$ or $\mathrm{H}_{2} \mathrm{O}_{2}$ plus Gyp for 24 hours. Total ROS was measured using the 6-Carboxy-20,70-Dichlorofluorescin diacetate (DCFH-DA) (Sigma, UK) according to the manufacturer's guidance. Briefly, cells were incubated with $10 \mathrm{mM}$ DCFH-DA in PBS $(150 \mu \mathrm{l} / \mathrm{well})$ and incubated for $30 \mathrm{~min}$ in an incubator with $5 \% \mathrm{CO}_{2}$ at $37^{\circ} \mathrm{C}$. The fluorescence was measured at $485 \mathrm{~nm}$ (excitation) and $520 \mathrm{~nm}$ (emission) using a Fluostar Optima microplate reader (BMG-labtech).

\subsection{Quantitative real-time polymerase chain reaction ( $q R T-P C R$ )}

Total RNA was extracted using Trizol Reagent (Sigma, UK) according to the manufacturer's protocol. cDNA was synthesized using a High-Capacity cDNA Reverse Transcription Kit (Applied Biosystems, UK). The quantification of gene expression was detected using a Platinum $®$ SYBR $®$ Green QPCR SuperMix-UDG w/ROX kit following the manufacturer's instructions (Invitrogen, UK). The relative change in gene expression was determined according to $2^{-\Delta \Delta C T}$ formula (Livak and Schmittgen, 2001) in which gene expression was normalized to expression of the housekeeping gene ( $\beta$-actin) in treated and control samples. The primers for qRTPCR are designed by referencing to published literature and the sequences are listed in Table 1.

\subsection{Biochemical assays}


Catalase (CAT) and superoxide dismutase (SOD) activities in treated and control RPE cells were measured using, respectively, the OxiSelect Catalase Activity Assay Kit (Cell Biolabs, STA-341) and the OxiSelect Superoxide Dismutase Activity Assay Kit (Cell Biolabs, STA-340), according to the manufacturer's protocols. Glutathione and malondialdehyde (MDA) levels were measured using the GSSG/GSH assay kit (Cell Biolabs, STA-312) and the TBARS assay kit (Cell Biolabs, STA-330) respectively, according to the manufacturer's instructions.

\subsection{Measurement of caspase-3 and -7 activities}

Caspase-Glo 3/7 assay (Promega) was used to measure the activities of caspase-3 and -7. ARPE-19 Cells (20,000 cells/well) were seeded in a 96 -well white plate overnight. The cells were incubated in the $5 \% \mathrm{CO}_{2}$ incubator at $37^{\circ} \mathrm{C}$ for $24 \mathrm{~h}$, then were treated with $\mathrm{H}_{2} \mathrm{O}_{2}$, or $\mathrm{H}_{2} \mathrm{O}_{2}$ plus Gyp for $24 \mathrm{~h}$. After the treatment $100 \mu \mathrm{L}$ of Caspase-Glo $3 / 7$ reagent was added and gently mixed for 30 seconds using a plate shaker at 300rpm. The plate was kept at room temperature for $3 \mathrm{~h}$ prior to measurement of luminescence.

\subsection{Enzyme-linked immunosorbent assay (ELISA)}

After cells were exposed to $\mathrm{H}_{2} \mathrm{O}_{2}$ or $\mathrm{H}_{2} \mathrm{O}_{2}$ plus Gyp for $24 \mathrm{~h}$, the culture medium was

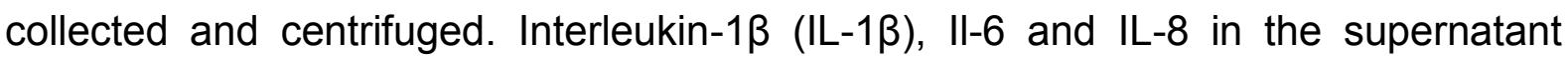
were measured using the Human IL-1 $\beta$ Mini ABTS ELISA Development Kit (900M95), IL-6 Mini ABTS ELISA Development Kit (900-M16) and IL-8 Mini ABTS ELISA Development Kit (900-M18), purchased from PeproTech, UK. Measurements were performed in a Nunc-Immuno ${ }^{\mathrm{TM}}$ MicroWell $^{\mathrm{TM}}$ 96-well solid plate (Sigma, UK) using a microplate reader and the concentration of unknown samples was calculated according to the manufacturer's protocols.

\subsection{Western blotting}


Cells were lysed with ice-cold RIPA lysis buffer (Thermo Scientific), following which the lysates were collected and centrifuged (16200g for 20 minutes). Protein concentration of the supernatants was determined using Precision Red Advanced Protein Assay reagent (Cat. number ADV02-A, Cytoskeleton, Inc.) according to the manufacturer's guidelines. Equal amounts of proteins were separated in SDS-PAGE and transferred electrophoretically to nitrocellulose membrane (Amersham Biosciences). The membrane was blocked with $5 \%$ skim milk for one hour at room temperature and incubated with primary antibodies (NRF2, Cell Signalling Technology, Cat. Number \#12721, 1:1000; GAPDH, Santa Cruz Biotechnology, Cat. Number sc-32233, 1:1000) overnight at $4^{\circ} \mathrm{C}$. The membrane was washed three times and incubated with secondary antibodies (1:10000) for one hour at room temperature. After washing, the signals were detected and analysed using the Image Studio $^{\text {TM }}$ Lite analysis software (LI-COR).

\subsection{Statistical analysis}

GraphPad Prism (version 6.0 from GraphPad software Inc. San Diego, CA, USA) was used for statistical analysis. All pairwise comparisons were performed using the nonparametric Mann-Whitney $U$ test. All multiple comparisons were carried out using the nonparametric Kruskal-Wallis with Dunn's multiple comparison test. Statistical significance was considered when a level of $p$ is less than 0.05 .

\section{Results}

\subsection{Effects of $\mathrm{H}_{2} \mathrm{O}_{2}$ and Gyp on cell viability}

$\mathrm{H}_{2} \mathrm{O}_{2}$ has been widely used to induce oxidative stress in in vitro studies. To determine an appropriate concentration of $\mathrm{H}_{2} \mathrm{O}_{2}$ for the current study, we used an MTT assay to assess viability in ARPE-19 cells exposed to $\mathrm{H}_{2} \mathrm{O}_{2}$ at different 
concentrations. ARPE-19 cells tolerated $\mathrm{H}_{2} \mathrm{O}_{2}$ treatment at concentrations of 50 to $500 \mu \mathrm{M}$ but exhibited significant decreases in viability at the doses of 750 and $1000 \mu \mathrm{M}$ (Fig. 1A). We also examined the potential toxicity of Gyp to ARPE-19 cells and found that there was no significant change in cell viability after 24 hours incubation with Gyp at 1, 2.5 or $5 \mu \mathrm{g} / \mathrm{ml}$ (Fig. 1B). However, Gyp at higher concentration $(7.5$ or $10 \mu \mathrm{g} / \mathrm{ml})$ had a toxic effect on RPE cells with a significant decrease in cell viability (Fig. 1B). Consequently, $\mathrm{H}_{2} \mathrm{O}_{2}$ at concentration of $750 \mu \mathrm{M}$ and Gyp at concentration of $5 \mu \mathrm{g} / \mathrm{ml}$ were applied in subsequent experiments. When ARPE-19 cells co-treated with $\mathrm{H}_{2} \mathrm{O}_{2}(750 \mu \mathrm{M})$ and Gyp $(5 \mu \mathrm{g} / \mathrm{ml})$ for 24 hours exhibited markedly increased cell viability by $55.00 \%$ when compared with cells exposed to $\mathrm{H}_{2} \mathrm{O}_{2}$ alone (Fig. $1 \mathrm{C}$ and D).

\subsection{Gyp protected against $\mathrm{H}_{2} \mathrm{O}_{2}$-induced cell death in RPE cells}

We examined whether increased cell viability by Gyp is associated with less cell death. We used TUNEL assay to determine cell death and found that there was marked increased cell death rate by 10 folds $(p=0.0286)$ in ARPE-19 cells incubated with $\mathrm{H}_{2} \mathrm{O}_{2}$ when compared to untreated control cells and that co-exposure to Gyp led to significant reduction $(p=0.0286)$ in cell death induced by $\mathrm{H}_{2} \mathrm{O}_{2}$ (Fig. $2 \mathrm{~A}$ and $\left.\mathrm{B}\right)$.

We also measured expression of cell death related genes, CASPASE 3 and 9 by qRT-PCR (Fig. 3 A). $\mathrm{H}_{2} \mathrm{O}_{2}$ treatment induced significantly increased expression of CASPASE 3 and 9 by, respectively, $258.00 \%$ and $55.14 \%$ in $\mathrm{H}_{2} \mathrm{O}_{2}$ treated cells compared to untreated control cells; co-treatment with Gyp resulted in significantly decreased expression of CASPASE 3 and 9 compared to cells treated with $\mathrm{H}_{2} \mathrm{O}_{2}$ alone. In addition, we measured CASPASE 3 and 9 activities and found that CASPASE 3 and 7 activities were markedly increased in cells exposed to $\mathrm{H}_{2} \mathrm{O}_{2}$ when 
compared to untreated cells. Co-treatment with Gyp resulted in significant decreases in CASPASE 3 and 7 activities compared to cells treated with $\mathrm{H}_{2} \mathrm{O}_{2}$ only (Fig. 3B).

\subsection{Gyp suppressed ROS production and up-regulated antioxidant gene expression}

We investigated whether Gyp can counter intracellular ROS production induced by $\mathrm{H}_{2} \mathrm{O}_{2}$ exposure in ARPE-19 cells. As shown in Fig. 4, cells exposed to $\mathrm{H}_{2} \mathrm{O}_{2}$ showed that ROS levels increased significantly by $61.75 \%$ compared to untreated cells. Cells co-treated with Gyp exhibited significantly decreased ROS by $30.37 \%$ compared to cells treated with $\mathrm{H}_{2} \mathrm{O}_{2}$ alone.

As ROS production causes cellular antioxidant imbalance, we examined expression of antioxidant genes in ARPE-19 cells exposed to $\mathrm{H}_{2} \mathrm{O}_{2}$ or $\mathrm{Gyp}+\mathrm{H}_{2} \mathrm{O}_{2}$. We found that expression of antioxidant genes was significantly decreased in $\mathrm{H}_{2} \mathrm{O}_{2}$ treated cells compared to untreated cells (Fig. 5). Compared to the untreated control group, expression of SOD1, GPX1, CAT, NQO-1 and GCLM genes in $\mathrm{H}_{2} \mathrm{O}_{2}$-treated cells was decreased by approximately 40\%. ARPE-19 cells co-incubated with Gyp showed notably increased expression of these genes when compared to cell incubated with $\mathrm{H}_{2} \mathrm{O}_{2}$ alone (Fig. 5): SOD1 expression was increased by $193.32 \%$; GPX1 expression was increased by $239.59 \%$; CAT expression was increased by 233.73\%; NQO-1 expression was increased by $204.90 \%$; and GCLM expression was increased by $241.68 \%$.

We also assessed the effects of Gyp on SOD and CAT activities. Activities of SOD and CAT were notably decreased in $\mathrm{H}_{2} \mathrm{O}_{2}$ treated cells by, respectively, $21.58 \%$ and $63.21 \%$, compared to untreated cells (Fig. $6 \mathrm{~A}$ and B). Co-treatment with Gyp resulted in significantly increased activities of SOD and CAT by, respectively, $139.11 \%$ and $327.45 \%$, compared to cells treated with $\mathrm{H}_{2} \mathrm{O}_{2}$ alone (Fig. $6 \mathrm{~A}$ and $\mathrm{B}$ ). 
3.4. Gyp reversed $\mathrm{H}_{2} \mathrm{O}_{2}$-induced changes in glutathione and malondialdehyde production

Glutathione (GSH) acts as an important antioxidant in every cell and tissue by preventing cellular damage caused by ROS. We measured the level of glutathione in $\mathrm{H}_{2} \mathrm{O}_{2}$-treated ARPE-19 cells and found that GSH was notably decreased by $79.80 \%$ compared to untreated cells. ARPE-19 cells co-treated with Gyp had markedly increased GSH by $2396.54 \%$ when compared to cells exposed solely to $\mathrm{H}_{2} \mathrm{O}_{2}$ (Fig. $6 \mathrm{C})$. We also investigated the level of MDA, a biomarker for lipid peroxidation, in $\mathrm{H}_{2} \mathrm{O}_{2}$-treated ARPE-19 cells and found that production of MDA was significantly increased by $333.30 \%$ when compared to untreated control cells. Co-treatment with Gyp led to significant decrease in MDA level by $79.65 \%$ compared to cells treated with $\mathrm{H}_{2} \mathrm{O}_{2}$ alone (Fig. 6D).

\subsection{Gyp reversed $\mathrm{H}_{2} \mathrm{O}_{2}$-induced changes in NRF2 expression}

NRF2 is a key transcription factor that upregulates expression of antioxidant genes and plays a protective role against oxidative stress (Ahmed et al., 2017). Firstly, we examined NRF2 expression by qRT-PCR and found that $\mathrm{H}_{2} \mathrm{O}_{2}$ treatment caused a significant decrease in NRF2 expression by $44.01 \%$ compared to untreated control cells. However, ARPE-19 cells co-treated with Gyp had a $283.23 \%$ increase of NRF2 expression compared to cells treated with $\mathrm{H}_{2} \mathrm{O}_{2}$ alone (Fig. 7A). Secondly, we determined NRF2 protein level by Western blotting using anti-NRF2 antibody (Fig. 7B) and found that the level of NRF2 protein level in ARPE-19 cells treated with $\mathrm{H}_{2} \mathrm{O}_{2}$ was notably decreased by $56.15 \%$ compared to untreated control cells. ARPE19 cells, co-incubated with Gyp, had a marked increase in NRF2 protein by $350.50 \%$ compared to cells incubated with $\mathrm{H}_{2} \mathrm{O}_{2}$ alone (Fig. $7 \mathrm{C}$ ). 
SESTRINs are a family of stress-inducible proteins that function in protection against oxidative stress. NRF2 is one of the transcription factors that upregulate sestrin expression (Lee et al., 2013). We examined expression of sestrins in treated and untreated ARPE-19 cells by qRT-PCR and found that ARPE-19 cells exposed to $\mathrm{H}_{2} \mathrm{O}_{2}$ had significant decreases in expression of SESTRIN1, 2, and 3 when compared to untreated cells (Fig. 7D). However, co-treatment with Gyp resulted in notably increased expression of SESTRIN1, 2 and 3 compared to cells treated with $\mathrm{H}_{2} \mathrm{O}_{2}$ alone (Fig. 7D).

\subsection{Gyp attenuated expression of inflammation genes induced by $\mathrm{H}_{2} \mathrm{O}_{2}$}

Inflammation has been implicated in the pathogenesis of a wide range of human diseases, including retinal degeneration (Whitcup et al., 2013). Oxidative stress and inflammation are closely associated, in that oxidative stress causes protein oxidation, leading to the release of inflammatory signals (Salzano et al., 2014). We measured mRNA levels of IL-1 $\beta, I L-6$ and IL-8 by qRT-PCR and found that $\mathrm{H}_{2} \mathrm{O}_{2}$ treatment led to significantly increased expression of IL-1 1 , IL-6 and IL-8 by, respectively, 205.32\%, 132.46\% and $89.76 \%$ compared to untreated cells (Fig.8A). ARPE-19 cells co-exposed to Gyp had significantly decreased expression of IL-1 $\beta$, II-6 and IL-8 compared to cells treated with $\mathrm{H}_{2} \mathrm{O}_{2}$ alone. We also examined protein levels of IL-1 $\beta$, IL-6 and II-8 by ELISA; similarly, $\mathrm{H}_{2} \mathrm{O}_{2}$ treatment caused significantly increased IL$1 \beta$, IL-6 and IL8 in ARPE-19 cells compared to untreated cells (Fig. 8B). Cotreatment with Gyp significantly counteracted these changes.

\subsection{Inhibition of NRF2 signalling pathway with Brusatol counteracted Gyp protection}

Ren et al. (2011) reported that Brusatol specifically inhibits the NRF2 pathway by selectively reducing NRF2 protein level through enhanced ubiquitination and degradation of NRF2. To confirm that the protective effect of Gyp against $\mathrm{H}_{2} \mathrm{O}_{2}-$ 
induced oxidative stress and inflammation was mediated by NRF2, we examined whether a reduced NRF2 level by Brusatol altered the effect of Gyp protection. Initially we treated ARPE-19 cells with Brusatol at 20, 30, 40, 50, 60 and 100nM, and found that Brusatol at high concentrations $(\geq 50 \mathrm{nM})$ had a toxic effect on RPE cells with a marked decrease in cell viability (Fig. 9A). Consequently, 40nM of Brusatol was applied for subsequent experiments. ARPE-19 cells exposed to Brusatol had a significant decrease in NRF2 protein level when compared to untreated cells (Fig. $9 \mathrm{~B})$; this is consistent with a previous report regarding Brusatol inhibition of NRF2 in A549 cells (Ren et al., 2011). Brusatol treatment also significantly reduced NRF2 level in Gyp and $\mathrm{H}_{2} \mathrm{O}_{2}$ co-treated ARPE-19 cells (Fig. 9B). We measured expression of SOD1, CAT, SESTRIN1 and IL-1 $\beta$ in untreated, $\mathrm{H}_{2} \mathrm{O}_{2}$-treated, $\mathrm{H}_{2} \mathrm{O}_{2}+\mathrm{Gyp}$-treated, and $\mathrm{H} 2 \mathrm{O} 2+\mathrm{Gyp}+$ Brusatol-treated cells by qRT-PCR. Again expression of SOD1, CAT and SESTRIN1 was markedly decreased in $\mathrm{H}_{2} \mathrm{O}_{2}$-exposed cells when compared to untreated cells, while Gyp co-treatment with $\mathrm{H}_{2} \mathrm{O}_{2}$ resulted in a significant increase in expression of the above three genes. However, cells exposed to $\mathrm{Gyp}+\mathrm{H}_{2} \mathrm{O}_{2}+$ Brusatol exhibited a significant decrease in expression of the three genes when compared to cells co-treated with Gyp and $\mathrm{H}_{2} \mathrm{O}_{2}$. By contrast, IL-1 $\beta$ expression was significantly increased in cells treated with $\mathrm{Gyp}+\mathrm{H}_{2} \mathrm{O}_{2}+$ Brusatol when compared to cells exposed to only Gyp $+\mathrm{H}_{2} \mathrm{O}_{2}$ (Fig. 9C).

\section{Discussion}

Inhibition of oxidative stress represents an effective approach to treat retinal degeneration. It would be of benefit to identify potent antioxidants from natural products. The present study evaluated the protective effects of Gyp in ARPE-19 cells and investigated underlying mechanisms. Gyp exposure reduced cell death, 
suppressed ROS production, promoted expression of antioxidant genes and inhibited inflammation in $\mathrm{H}_{2} \mathrm{O}_{2}$-treated ARPE-19 cells. These effects appear to be associated with activated NRF2 signal pathway, since Gyp treatment enhanced NRF2 expression.

Gyp, the main active saponin of G. pentaphyllum, have been shown to improve cognitive impairment in rats with experimentally induced cerebral hypoperfusion through enhancing antioxidant capacity and by reducing lipid peroxidation and oxidative DNA damage (Zhang et al., 2011). In an in vitro Parkinson's disease model, Gyp protected dopaminergic neurons from $\mathrm{MPP}^{+}$-induced oxidative injury (Wang et al., 2010). Gyp treatment of dopaminergic neurons exposed to $\mathrm{MTT}^{+}$ resulted in significantly decreased ROS production, lipid peroxidation, and levels of carbonyl and 8-hydroxyguanine. Gyp treatment also led to markedly increased activities of GPX, SOD and catalase, and notably increased GSH content (Zhang et al., 2011). Shang et al. (2006) showed that Gyp protected rat primary cortical cells from glutamate-induced toxicity by increasing GSH level and reducing MDA level (Shag et al., 2006). In a myocardial ischemia-reperfusion rat model, Gyp pretreatment resulted in significantly increased activities of SOD and GPX and decreased MDA level in the myocardium; Gyp pre-treatment also preserved myocardial mitochondrial function by increasing the activities of complex I, II and III, and decreasing the release of cytochrome c (Yu et al., 2016b). Similarly, in a hepatic ischemia-reperfusion injury mouse model, Gyp treatment provided protection of hepatic tissues from ischemia-reperfusion injury through inhibition of lipid peroxidation, downregulation of heme oxygenase-1 (HO1) and an increased GSH level (Zhao et al., 2014). Our present study evaluated the protective effects of Gyp in an in vitro ARPE-19 cell model. We too found that Gyp treatment led to notably 
increased activities of antioxidant enzymes (SOD and catalase) and GSH (Fig. 6AC), and that ROS and MDA (Fig. 4 and Fig. 6D) were significantly decreased.

Previous studies demonstrated that Gyp inhibited inflammation in vitro and in vivo. The nuclear factor kappa (NF-kB) pathway is involved in production of proinflammatory cytokine and chemokine, and in recruitment of leukocytes (Lawrence, 2009). Activation of NF-kB is regulated by several signal pathways, e.g. the MAPK and PI3K/Akt pathways. It has been reported that NF-kB can be upregulated through phosphorylation of IKK- $\beta$ by $p 38$, JNK and ERK activation (Huang et al., 2008; Slomiany and Slomiany, 2013; Yeh et al., 2011). Previous studies have demonstrated that Gyp treatment inhibited LPS-induced NF-kB activation in murine macrophage (RAW264.7) cells and IL-1 $\beta$-induced NF-kB activation in human osteoarthritis chondrocytes (Aktan et al., 2003; Wan and Zhao, 2017). Yu et al. (2016a) reported that Gyp treatment suppressed NF-kB activation by inhibition of MAPK pathway in both oxygen-glucose deprivation-reoxygenation H9c2 cell model and ischemia-reperfusion injury rat model (Yu et al., 2016a). Gyp exposure has also been shown to result in decreased production of pro-inflammatory cytokines in a renal ischemia/reperfusion injury mouse model and in $\beta$ amyloidincubated N9 microglia cells (Cai et al., 2016; Ye et al., 2016). Interestingly, a recent study demonstrated that Gyp treatment attenuated inflammation in the retina and optic nerve in a mouse model of experimental autoimmune optic neuritis (Zhang et al., 2017). We found that Gyp treatment suppressed $\mathrm{H}_{2} \mathrm{O}_{2}$-induced inflammation in ARPE-19 cells by reducing the expression of pro-inflammatory cytokines (IL-1 $1 \beta$, IL-6 and IL-8) at mRNA and protein levels (Fig. 8).

$\mathrm{H}_{2} \mathrm{O}_{2}$-induced oxidative stress causes cell death in ARPE-19 cells. Early reports suggested that apoptosis is a major type of cell death in ARPE-19 cells treated with 
$\mathrm{H}_{2} \mathrm{O}_{2}$ (Faghiri and Bazan, 2010; Kim et al., 2010). A recent study showed that ARPE19 cells exposed to $\mathrm{H}_{2} \mathrm{O}_{2}$ had autophagy-associated cell death (Szatmári-Tóth et al., 2016). However, Hanus et al demonstrated that necrosis, rather than apoptosis or autophagy, is a major type of cell death in ARPE-19 cells exposed to $\mathrm{H}_{2} \mathrm{O}_{2}$ (Hanus et al., 2013). Our data here showed that $\mathrm{H}_{2} \mathrm{O}_{2}$ exposure caused caspase-dependent apoptosis in ARPE-19 cells which had significant increases in mRNA level of Caspase $3 / 9$ and the activities of Caspase $3 / 7$ (Fig. 3), although we could not exclude other cell death pathways induced by $\mathrm{H}_{2} \mathrm{O}_{2}$ treatment. An earlier study demonstrated that Gyp treatment protected rat cortical cells from glutamate-induced apoptosis by increasing the level of anti-apoptotic Bcl-2 and inhibiting pro-apoptotic Bax (Shang et al., 2006). Recent studies showed that Gyp suppressed apoptosis in cardiomycocytes in a myocardial ischemia-reperfusion injury rat model (Yu et al., 2016c) and inhibited renal cell apoptosis in a renal ischemia-reperfusion injury mouse model (Ye et al., 2016), both through upregulation of Bcl-2 and dowregulation of Bax. Gyp treatment also inhibited hepatic cell apoptosis in a mouse hepatic ischemia-reperfusion injury model by increasing Bcl-2 expression and decreasing protein levels of Bax and cytochrome c, and the activities of Caspase 3/8 (Zhao et al., 2014). Our current study demonstrated that Gyp downregulated the expression of Caspase 3, 7 and 9 (Fig. 3), which are important indicators of apoptosis.

Under oxidative stress, NRF2 transcriptionally upregulates expression of endogenous antioxidants and phase II detoxifying enzymes through the antioxidant response elements (AREs). NRF2 also contributes to anti-inflammation by regulating the expression of HO-1, COX2, iNOS and NFKB (Ahmed et al., 2017; Kowluru and Mishra, 2015). NRF2 plays an important role in protection of retinal cells from oxidative damage. Deletion of NRF2 in mouse resulted in age-dependent RPE 
deterioration (Zhao et al., 2011). Adeno associated virus (AAV) over-expression of NRF2 in retinal degeneration mouse models attenuated photoreceptor cell death (Xiong et al., 2015). Natural products such as carnosic acid can activate NRF2 in ARPE-19 cells and upregulate antioxidant genes (Albalawi et al., 2017). Our results demonstrated that ARPE-19 cells treated with Gyp had increased NRF2 transcripts and protein (Fig. 7), which consequently upregulated the expression of ARE-bearing genes (Fig. 5).

Oxidative stress and inflammation play a critical role in the pathogenesis of complex retinal diseases, including age-related macular degeneration, diabetic retinopathy and glaucoma (Datta et al., 2017; Pinazo-Durán et al., 2015; Kowluru and Mishra, 2015). Progression of inherited photoreceptor degeneration, such as retinitis pigmentosa, is also associated with oxidative stress and inflammation (Zhang et al., 2017). While the current study evaluated Gyp function in RPE cells, it would be of benefit to evaluate the capability of Gyp to protect against oxidative stress and inflammation in a photoreceptor cell line (e.g. 661W) and a ganglion cell line (e.g. RGC-5). The limitation of the current study is that the therapeutic potential of Gyp was assessed in vitro. An in vivo evaluation of Gyp mediated protection against oxidative stress and inflammation is required in animal models, such as retinal light damage (Organisciak and Vaughan, 2010) and inherited photoreceptor degeneration (Vlachantoni et al., 2011) rodent models. Following successful preclinical experiments, Gyp could be used in clinical trials to treat patients with retinal diseases.

In summary, our study demonstrates that Gyp can protect RPE cells from $\mathrm{H}_{2} \mathrm{O}_{2}$ induced oxidative damages through activation of the NRF2 signalling pathway and has a potential for the treatment of patients with retinal diseases in the near future. 


\section{Competing interests}

The authors declare no competing financial interest.

\section{Acknowledgement}

This work was supported by a Saudi Arabia government PhD scholarship, the Rosetrees Trust (M160 and M160-F1), the Fight for Sight, the Glasgow Children's Hospital Charity (YRSS/PSG/2014), and the Visual Research Trust (VR2014).

\section{REFERENCES}

Ahmed, S.M., Luo, L., Namani, A., Wang, X.J., Tang, X., 2017. Nrf2 signaling pathway: Pivotal roles in inflammation. Biochim Biophys Acta 1863, 585-597. Aktan, F., Henness, S., Roufogalis, B.D., Ammit, A.J., 2003. Gypenosides derived from Gynostemma pentaphyllum suppress NO synthesis in murine macrophages by inhibiting iNOS enzymatic activity and attenuating NF-kappaB-mediated iNOS protein expression. Nitric Oxide 8, 235-242.

Albalawi, A., Alhasani, R.H., Biswas, L., Reilly, J., Shu, X., 2017. Protective effect of carnosic acid against acrylamide-induced toxicity in RPE cells. Food Chem Toxicol. 108(Pt B), 543-553.

Cai, H., Liang, Q., Ge, G., 2016. Gypenoside Attenuates $\beta$ Amyloid-Induced Inflammation in N9 Microglial Cells via SOCS1 Signaling. Neural Plast 2016, 6362707.

Choi, H.S., Park, M.S., Kim, S.H., Hwang, B.Y., Lee, C.K., Lee, M.K., 2010. Neuroprotective effects of herbal ethanol extracts from Gynostemma pentaphyllum in the 6-hydroxydopamine-lesioned rat model of Parkinson's disease. Molecules 15, 2814-2824. 
Cui, J., Eneroth, P., Bruhn, J.G., 1999. Gynostemma pentaphyllum: identification of major sapogenins and differentiation from Panax species. Eur J Pharm Sci. 8,187191.

Danielson, S.R., Andersen, J.K., 2008. Oxidative and nitrative protein modifications in Parkinson's disease. Free Radic Biol Med. 44,1787-1794.

Datta, S., Cano, M., Ebrahimi, K., Wang, L., Handa, J.T., 2017. The impact of oxidative stress and inflammation on RPE degeneration in non-neovascular AMD. Prog Retin Eye Res. 60, 201-218.

Faghiri, Z., Bazan, N.G., 2010. PI3K/Akt and mTOR/p70S6K pathways mediate neuroprotectin D1-induced retinal pigmentepithelial cell survival during oxidative stress-induced apoptosis. Exp Eye Res. 90, 718-725.

Gou, S.H., Huang, H.F., Chen, X.Y., Liu, J., He, M., Ma, Y.Y., Zhao, X.N., Zhang, Y., Ni, J.M., 2016. Lipid-lowering, hepatoprotective, and atheroprotective effects of the mixture Hong-Qu and gypenosides in hyperlipidemia with NAFLD rats. J Chin Med Assoc. 79, 111-121.

Hanus, J., Zhang, H., Wang, Z., Liu, Q., Zhou, Q., Wang, S., 3013. Induction of necrotic cell death by oxidative stress in retinal pigment epithelial cells. Cell Death Dis. 4, e965.

He, Q., Li, J.K., Li, F., Li, R.G., Zhan, G.Q., Li, G., Du, W.X., Tan, H.B., 2015.

Mechanism of action of gypenosides on type 2 diabetes and non-alcoholic fatty liver disease in rats. World J Gastroenterol. 21, 2058-2066.

Huang, L.Y., 2008. Miyabenol A inhibits LPS-induced NO production via IKK/lkB inactivation in RAW 264.7 macrophages: possible involvement of the p38 and P13K pathways. J. Agric. Food Chem. 56, 8911-8918. 
Huang, T.H., Li, Y., Razmovski-Naumovski, V., Tran, V.H., Li, G.Q., Duke, C.C., Roufogalis, B.D., 2006. Gypenoside XLIX isolated from Gynostemma pentaphyllum inhibits nuclear factor-kappaB activation via a PPAR-alpha-dependent pathway. J Biomed Sci. 13, 535-548.

Kim, J.H., Kim, J.H., Jun, H.O., Yu, Y.S., Min, B.H., Park, K.H., Kim, K.W., 2010. Protective effect of clusterin from oxidative stress-induced apoptosis in human retinal pigmentepithelial cells. Invest Ophthalmol Vis Sci. 51, 561-566.

Kong, L., Wang, X., Zhang, K., Yuan, W., Yang, Q., Fan, J., Wang, P., Liu, Q., 2015. Gypenosides Synergistically Enhances the Anti-Tumor Effect of 5-Fluorouracil on Colorectal Cancer In Vitro and In Vivo: A Role for Oxidative Stress-Mediated DNA Damage and p53 Activation. PLoS One 10, e0137888.

Lawrence, T., 2009. The Nuclear Factor NF-kB Pathway in Inflammation. Cold Spring Harb Perspect Biol. 1, a001651.

Kowluru, R.A., Mishra, M., 2015. Oxidative stress, mitochondrial damage and diabetic retinopathy. Biochim Biophys Acta 1852, 2474-2483.

Kujoth, G.C., Hiona, A., Pugh, T.D., Someya, S., Panzer, K., Wohlgemuth, S.E., Hofer, T., Seo, A.Y., Sullivan, R., Jobling, W.A., Morrow, J.D., Van Remmen, H., Sedivy, J.M., Yamasoba, T., Tanokura, M., Weindruch, R., Leeuwenburgh, C., Prolla, T.A., 2005. Mitochondrial DNA mutations, oxidative stress, and apoptosis in mammalian aging. Science 309, 481-484.

Lee, J.H., Budanov, A.V., Karin, M., 2013. Sestrins orchestrate cellular metabolism to attenuate aging. Cell Metab. 18, 792-801.

Li, H., Ying, H., Hu, A., Hu, Y., Li, D., 2017. Therapeutic Effect of Gypenosides on Nonalcoholic Steatohepatitis via Regulating Hepatic Lipogenesis and Fatty Acid Oxidation. Biol Pharm Bull. 40, 650-657. 
Li, K., Du, Y., Fan, Q., Tang, C.Y., He, J.F., 2014. Gypenosides might have neuroprotective and immunomodulatory effects on optic neuritis. Med Hypotheses. $82,636-638$.

Megalli, S., Aktan, F., Davies, N.M., Roufogalis, B.D., 2005. Phytopreventative antihyperlipidemic effects of gynostemma pentaphyllum in rats. J Pharm Pharm Sci. 8, 507-515.

Moreira, P.I., Nunomura, A., Nakamura, M., Takeda, A., Shenk, J.C., Aliev, G., Smith, M.A., Perry, G., 2008. Nucleic acid oxidation in Alzheimer disease. Free Radic Biol Med. 44, 1493-1505.

Organisciak, D.T. and Vaughan, D.K., 2010. Retinal light damage: mechanisms and protection. Prog Retin Eye Res. 29, 113-134.

Pinazo-Durán, M.D., Zanón-Moreno, V., Gallego-Pinazo, R., García-Medina, J.J., 2015. Oxidative stress and mitochondrial failure in the pathogenesis of glaucoma neurodegeneration. Prog Brain Res. 220, 127-153.

Punzo, C., Xiong, W., Cepko, C.L., 2012. Loss of daylight vision in retinal degeneration: are oxidative stress and metabolic dysregulation to blame? J Biol Chem. 287, 1642-1648.

Qin, R., Zhang, J., Li, C., Zhang, X., Xiong, A., Huang, F., Yin, Z., Li, K., Qin, W., Chen, M., Zhang, S., Liang, L., Zhang, H., Nie, H., Ye, W., 2012. Protective effects of gypenosides against fatty liver disease induced by high fat and cholesterol diet and alcohol in rats. Arch Pharm Res. 35, 1241-1250.

Razmovski-Naumovski, V., Huang, T., Tran, V., Li, G., Duke, C., Roufogalis, B., 2005. Chemistry and pharmacology of Gynostemma pentaphyllum. Phytochem. Rev. 4, 197-219. 
Ren, D., Villeneuve, N.F., Jiang, T., Wu, T., Lau, A., Toppin, H.A., Zhang, D.D., 2011. Brusatol enhances the efficacy of chemotherapy by inhibiting the Nrf2mediated defense mechanism. Proc Natl Acad Sci U S A. 108, 1433-1438.

Salzano, S., Checconi, P., Hanschmann, E.M., Lillig, C.H., Bowler, L.D., Chan, P., Vaudry, D., Mengozzi, M., Coppo, L., Sacre, S., Atkuri, K.R., Sahaf, B., Herzenberg, L.A., Herzenberg, L.A., Mullen, L., Ghezzi, P., 2014. Linkage of inflammation and oxidative stress via release of glutathionylated peroxiredoxin-2, which acts as a danger signal. Proc Natl Acad Sci U S A. 111, 12157-12162.

Shang, L., Liu, J., Zhu, Q., Zhao, L., Feng, Y., Wang, X., Cao, W., Xin, H., 2006. Gypenosides protect primary cultures of rat cortical cells against oxidative neurotoxicity. Brain Res. 1102, 163-174.

Shaw, P.X., Stiles, T., Douglas, C., Ho, D., Fan, W., Du, H., Xiao, X., 2016. Oxidative stress, innate immunity, and age-related macular degeneration. AIMS Mol Sci.

3,196-221.

Slomiany, B.L., Slomiany, A., 2013. Induction in gastric mucosal prostaglandin and nitric oxide by Helicobacter pylori is dependent on MAPK/ERK-mediated activation of IKK- $\beta$ and cPLA2: modulatory effect of ghrelin. Inflammopharmacology 21, 241-251.

Strauss, O., 2005. The retinal pigment epithelium in visual function. Physiol Rev. 85, 845-881.

Szatmári-Tóth, M., Kristóf, E., Veréb, Z., Akhtar, S., Facskó, A., Fésüs, L., Kauppinen, A., Kaarniranta, K., Petrovski, G., 2016. Clearance of autophagyassociated dying retinal pigment epithelial cells - a possible source for inflammation in age-related macular degeneration. Cell Death Dis. 7, e2367.

Vlachantoni, D., Bramall, A.N., Murphy, M.P., Taylor, R.W., Shu, X., Tulloch, B., Van Veen, T., Turnbull, D.M., Mclnnes, R.R., Wright, A.F., 2011. Evidence of severe 
mitochondrial oxidative stress and a protective effect of low oxygen in mouse models of inherited photoreceptor degeneration. Hum Mol Genet. 20, 322-335.

Wan, Z.H., Zhao, Q., 2017. Gypenoside inhibits interleukin-1 $\beta$-induced inflammatory response in human osteoarthritis chondrocytes. J Biochem Mol Toxicol. 31(9). doi: 10.1002/jbt.21926. Epub 2017 Apr 19.

Wang, P., Niu, L., Gao, L., Li, W.X., Jia, D., Wang, X.L., Gao, G.D., 2010. Neuroprotective effect of gypenosides against oxidative injury in the substantia nigra of a mouse model of Parkinson's disease. J Int Med Res. 38,1084-1092 Whitcup, S.M., Nussenblatt, R.B., Lightman, S.L., Hollander, D.A., 2013. Inflammation in retinal disease. Int J Inflam. 2013, 724648.

Xie, Z., Huang, H., Zhao, Y., Shi, H., Wang, S., Wang, T.T., Chen, P., Yu, L.L., 2012. Chemical composition and anti-proliferative and anti-inflammatory effects of the leaf and whole-plant samples of diploid and tetraploid Gynostemma pentaphyllum (Thunb.) Makino. Food Chem. 132, 125-133.

Xiong, W., MacColl Garfinkel, A.E., Li, Y., Benowitz, L.I., Cepko, C.L., NRF2 promotes neuronal survival in neurodegeneration and acute nerve damage. $\mathrm{J}$ Clin Invest. 125, 1433-1445.

Yan, H., Wang, X., Niu, J., Wang, Y., Wang, P., Liu, Q., 2014. Anti-cancer effect and the underlying mechanisms of gypenosides on human colorectal cancer SW-480 cells. PLoS One 9, e95609.

Yang, Y.H., Yang, J., Jiang, Q.H., 2013. Hypolipidemic effect of gypenosides in experimentally induced hypercholesterolemic rats. Lipids Health Dis. 12, 154.

Ye, Q., Zhu, Y.I., Ye, S., Liu, H., She, X., Niu, Y., Ming, Y., 2016.

Gypenoside attenuates renal ischemia/reperfusion injury in mice by inhibition of ERK signaling. Exp Ther Med. 11, 1499-1505. 
Yeh, J.L., Hsu, J.H., Hong, Y.S., Wu, J.R., Liang, J.C., Wu, B.N., Chen, I.J., Liou, S.F., 2011. Eugenolol and glyceryl-isoeugenol suppress LPS-induced iNOS expression by down-regulating NF-KB AND AP-1 through inhibition of MAPKS and AKT/IKBa signaling pathways in macrophages. Int. J. Immunopathol. Pharmacol. 24, 345-356.

Yu, D.Y., Cringle, S.J., 2005. Retinal degeneration and local oxygen metabolism. Exp Eye Res. 80, 745-751.

Yu, H., Shi, L., Qi, G., Zhao, S., Gao, Y., Li, Y., 2016a. Gypenoside Protects Cardiomyocytes against Ischemia-Reperfusion Injury via the Inhibition of MitogenActivated Protein Kinase Mediated Nuclear Factor Kappa B Pathway In Vitro and In Vivo. Front Pharmacol. 7:148.

Yu, H., Guan, Q., Guo, L., Zhang, H., Pang, X., Cheng, Y., Zhang, X., Sun, Y., 2016b. Gypenosides alleviate myocardial ischemia-reperfusion injury via attenuation of oxidative stress and preservation of mitochondrial function in rat heart. Cell Stress Chaperones 21, 429-437.

Yu, H., Zhang, H., Zhao, W., Guo, L., Li, X., Li, Y., Zhang, X., Sun, Y., 2016c. Gypenoside Protects against Myocardial Ischemia-Reperfusion Injury by Inhibiting Cardiomyocytes Apoptosis via Inhibition of CHOP Pathway and Activation of PI3K/Akt Pathway In Vivo and In Vitro. Cell Physiol Biochem. 39, 123-136.

Zhang, G.L., Deng, J.P., Wang, B.H., Zhao, Z.W., Li, J., Gao, L., Liu, B.L., Xong, J.R., Guo, X.D., Yan, Z.Q., Gao, G.D., 2011. Gypenosides improve cognitive impairment induced by chronic cerebral hypoperfusion in rats by suppressing oxidative stress and astrocytic activation. Behav Pharmacol. 22, 633-644. 
Zhang, H.K., Ye, Y., Zhao, Z.N., Li, K.J., Du, Y., Hu, Q.M., He, J.F., 2017. Neuroprotective effects of gypenosides in experimental autoimmune optic neuritis. Int J Ophthalmol. 10, 541-549.

Zhang, X., Tohari, A.M., Marcheggiani, F., Zhou, X., Reilly, J., Tiano, L., Shu, X., 2017. Therapeutic potential of co-enzyme Q10 in retinal diseases. Curr Med Chem. doi: 10.2174/0929867324666170801100516. [Epub ahead of print] Zhao, J., Ming, Y., Wan, Q., Ye, S., Xie, S., Zhu, Y., Wang, Y., Zhong, Z., Li, L., Ye, Q., 2014. Gypenoside attenuates hepatic ischemia/reperfusion injury in mice via antioxidative and anti-apoptotic bioactivities. Exp Ther Med. 7, 1388-1392.

Zhao, Z., Chen, Y., Wang, J., Sternberg, P., Freeman, M.L., Grossniklaus, H.E., Cai, J., 2011. Age-related retinopathy in NRF2-deficient mice. PLoS One 6, e19456. 
Table 1 The primers used for qRT-PCR

\begin{tabular}{|c|c|c|c|c|}
\hline Genes & Forward primers 5'-3' & Reverse primers 5'-3' & $\begin{array}{c}\text { Annealing } \\
\text { temperature } \\
{ }^{\circ} \mathrm{C}\end{array}$ & $\begin{array}{c}\text { PCR } \\
\text { product (bp) }\end{array}$ \\
\hline GPX 1 & AGTCCACCGTGTATGCCTTC & CTCCTGGTGTCCGAACTGAT & 57.0 & 218 \\
\hline SOD 1 & AGGGCATCATCAATTTCGAG & CATTGCCCAAGTCTCCAAC & 55.0 & 217 \\
\hline CAT & ATCTCGTTGGAAATAACACC & AGAAACCTGATGCAGAGACT & 57.5 & 161 \\
\hline NQO-1 & CCTCTATGCCATGAACTT & TATAAGCCAGAACAGACTC & 48.6 & 107 \\
\hline GCLM & GCCATAGGTACCTCTGATC & CTTGACAGACAACATACTGTC & 51.2 & 487 \\
\hline NRF2 & AGTGGATCTGCCAACTACTC & CATCTACAAACGGGAATGTCTG & 56.5 & 106 \\
\hline SESTRIN1 & CTTCTGGAGGCAGTTCAAGC & TGAATGGCAGCCTGTCTTCAC & 60.0 & 341 \\
\hline SESTRIN2 & CAAGCTCGGAATTAATGTGCC & CTCACACCATTAAGCATGGAG & 57.0 & 323 \\
\hline SESTRIN3 & $\begin{array}{c}\text { GTTCACTGTATGTTTGGAATCA } \\
\text { GG }\end{array}$ & GGGTGATACTTCAGGTCAAATG & 58.0 & 265 \\
\hline IL $1-\beta$ & GCTGAGGAAGATGCTGGTTC & TCCATATCCTGTCCCTGGAG & 57.5 & 213 \\
\hline IL-6 & ATGTAGCCGCCCCACACAGA & CATCCATCTTTTTCAGCCAT & 60.0 & 190 \\
\hline IL-8 & GTGCAGTTTTGCCAAGGAGT & ACTTCTCCACAACCCTCTGC & 57.5 & 210 \\
\hline CASPASE 3 & AACTGGACTGTGGCATTG & ACCAGGTGCTGTGGAGTA & 54.3 & 107 \\
\hline CASPASE 9 & $\begin{array}{c}\text { ATGGACGAAGCGGATCGGCGG } \\
\text { CTCC }\end{array}$ & GCACCACTGGGGTAAGGTTTTCTAG & 64 & 331 \\
\hline$\beta-A C T I N$ & TCCACGAAACTACCTTCAACTC & GTCATACTCCTGCTTGCTGAT & 57.5 & 269 \\
\hline
\end{tabular}




\section{Figure legends}

\section{Figure 1}

The effects of $\mathrm{H}_{2} \mathrm{O}_{2}$ and gypenosides (Gyp) on cell viability. (A) ARPE-19 cells treated with $\mathrm{H}_{2} \mathrm{O}_{2}$ at different concentration for 24 hours showed decreases in cell viability at higher concentrations when compare to untreated control cells. Data were represented as mean $\pm S D(n=5) .{ }^{*} P<0.05,{ }^{* *} P<0.01$, Kruskal-Wallis test with Dunn's multiple comparisons. (B) ARPE-19 cells exposed to different concentrations of Gyp for 24 hours showed decreased cell viability at higher concentrations when compare to untreated control cells. Data were represented as mean $\pm S D(n=5)$. * $P<$ $0.05,{ }^{* *} \mathrm{P}<0.01$, Kruskal-Wallis test with Dunn's multiple comparisons. (C) Microscopic images of untreated ARPE-19 cells and of cells treated with $\mathrm{H}_{2} \mathrm{O}_{2}$ $(750 \mu \mathrm{M})$ alone or with $\mathrm{H}_{2} \mathrm{O}_{2}(750 \mu \mathrm{M})$ plus Gyp $(5 \mu \mathrm{g} / \mathrm{ml})$. Inserts show a $4 \times$ magnification of the selected regions. UT, untreated control cells. (D) Gyp treatment countered $\mathrm{H}_{2} \mathrm{O}_{2}$-induced toxic effects. Data were represented as mean $\pm \operatorname{SEM}(n=4)$. ${ }^{*} \mathrm{P}<0.05$, Mann Whitney test.

\section{Figure 2}

Gyp treatment of ARPE-19 cells significantly decreased apoptosis in caused by $\mathrm{H}_{2} \mathrm{O}_{2}$ and detected by a TUNEL assay. (A) ARPE-19 cells were exposed to $750 \mu \mathrm{M}$ of $\mathrm{H}_{2} \mathrm{O}_{2}$ only, $750 \mu \mathrm{M}$ of $\mathrm{H}_{2} \mathrm{O}_{2}+5 \mu \mathrm{g} / \mathrm{ml}$ Gyp, for $24 \mathrm{~h}$ then stained with TUNEL reagents to detect apoptotic cells and co-staining with DAPI to label nuclei. Cells treated with DNase were used as positive control for apoptosis. (B) Apoptotic cell number was quantified in 300 cells and presented as percentage. Data were presented as means $\pm \operatorname{SEM}(n=9) .{ }^{*} p<0.05$, Mann Whitney test. UT: untreated control cells 


\section{Figure 3}

$\mathrm{H}_{2} \mathrm{O}_{2}$ exposure led to notably increased expression of CASPASE which was counteracted by Gyp. (A, B) Increased expression (mRNA) of CASPASE 3 and 9 in ARPE-19 cells treated with $750 \mu \mathrm{M}$ of $\mathrm{H}_{2} \mathrm{O}_{2}$ only for $24 \mathrm{~h}$, co-treatment of Gyp $(5 \mu \mathrm{g} / \mathrm{ml})$ reversed the effect. mRNA was measured by qRT-PCR. (C) CASPASE 3/7 activity of ARPE-19 cells untreated (UT), or treated with $750 \mu \mathrm{M}$ of $\mathrm{H}_{2} \mathrm{O}_{2}$ only, or 750 $\mu \mathrm{M}$ of $\mathrm{H}_{2} \mathrm{O}_{2}$ plus $5 \mu \mathrm{g} / \mathrm{ml}$ Gyp for $24 \mathrm{~h}$ were measured using CASPASE-Glo 3/7 assay. Co-exposure to Gyp significantly decreased CASPASE 3/7 activities. Data were presented as mean \pm SEM $(n=9)$. ${ }^{*} p<0.05$, Mann Whitney test. UT: untreated control cells.

\section{Figure 4}

Co-treatment with Gyp suppressed $\mathrm{H}_{2} \mathrm{O}_{2}$-induced ROS production. ARPE-19 cells were exposed to $750 \mu \mathrm{M} \mathrm{H} \mathrm{O}_{2}$ only or to $750 \mu \mathrm{M}$ of $\mathrm{H}_{2} \mathrm{O}_{2}$ plus $5 \mu \mathrm{g} / \mathrm{ml}$ Gyp. The intracellular reactive oxygen species (ROS) was measured using DCFH-DA staining. Data were presented as mean $\pm \operatorname{SEM}(n=9) .{ }^{* *} p<0.01$, Mann Whitney test. UT: untreated control cells.

\section{Figure 5}

$\mathrm{H}_{2} \mathrm{O}_{2}$ exposure led to notably decreased expression of antioxidant genes and cotreatment with $5 \mu \mathrm{g} / \mathrm{ml}$ Gyp reversed the effects. Expression of SOD1 (A), GPX1 (B), Catalase (C), NQO-1 (D) and GCLM (E) in ARPE-19 cells untreated (UT) or treated with $750 \mu \mathrm{M} \mathrm{H}_{2} \mathrm{O}_{2}$ only, or $750 \mu \mathrm{M} \mathrm{H}_{2} \mathrm{O}_{2}$ plus $5 \mu \mathrm{g} / \mathrm{ml}$ Gyp for $24 \mathrm{~h}$ were measured by qRT-PCR. Data were presented as mean \pm SEM $(n=9) .{ }^{*} p<0.05$, Mann Whitney test. CAT: catalase. 


\section{Figure 6}

Gyp treatment reversed $\mathrm{H}_{2} \mathrm{O}_{2}$-induced effects on the activities of SOD and CAT, and the level of GSH and MDA. Activities of SOD (A) and CAT (B) were markedly decreased in ARPE-19 cells challenged with $\mathrm{H}_{2} \mathrm{O}_{2}$ alone for $24 \mathrm{~h}$, and notably increased during co-treatment with $5 \mu \mathrm{g} / \mathrm{ml}$ Gyp. (C) GSH generation was significantly decreased in ARPE-19 cells treated with $\mathrm{H}_{2} \mathrm{O}_{2}$ alone for $24 \mathrm{~h}$, and were notably increased during co-exposure to $5 \mu \mathrm{g} / \mathrm{ml}$ Gyp. (D) MDA production was significantly increased in ARPE-19 cells treated with $\mathrm{H}_{2} \mathrm{O}_{2}$ alone for $24 \mathrm{~h}$, and notably decreased during co-exposure to $5 \mu \mathrm{g} / \mathrm{ml}$ Gyp. Data were presented as mean \pm SEM $(n=9) .{ }^{*} p<0.05$, Mann Whitney test. UT: untreated control cells.

\section{Figure 7}

$\mathrm{H}_{2} \mathrm{O}_{2}$ exposure decreased the expression of NRF2 while co-treatment with $5 \mu \mathrm{g} / \mathrm{ml}$ Gyp reversed the effects. (A) Expression levels of NRF2 in ARPE-19 cells untreated (UT), or treated with $750 \mu \mathrm{M}$ of $\mathrm{H}_{2} \mathrm{O}_{2}$ alone or with $750 \mu \mathrm{M} \mathrm{H}_{2} \mathrm{O}_{2}$ plus $5 \mu \mathrm{g} / \mathrm{ml}$ Gyp for $24 \mathrm{~h}$, were measured by qRT-PCR. (B) NRF2 protein in ARPE-19 cells treated with $750 \mu \mathrm{M}$ of $\mathrm{H}_{2} \mathrm{O}_{2}$ alone or with $750 \mu \mathrm{M}$ of $\mathrm{H}_{2} \mathrm{O}_{2}+5 \mu \mathrm{g} / \mathrm{ml}$ Gyp ACR for $24 \mathrm{~h}$ was examined by Western blotting. (C) Quantification of NRF2 protein levels was normalized with GAPDH protein. (D-F) $\mathrm{H}_{2} \mathrm{O}_{2}$ exposure led to notably decreased expression of Sestrin (SESN) genes while co-exposure of $5 \mu \mathrm{g} / \mathrm{ml}$ Gyp reversed the effects. mRNA levels of SESN1, SESN2 and SESN3 in ARPE-19 cells treated with $750 \mu \mathrm{M} \mathrm{H} \mathrm{O}_{2}$ alone or with $750 \mu \mathrm{M} \mathrm{H}_{2} \mathrm{O}_{2}$ plus $5 \mu \mathrm{g} / \mathrm{ml}$ Gyp for $24 \mathrm{~h}$ were measured by $q R T-P C R$. Data were presented as mean \pm SEM $(n=9) .{ }^{*} p<0.05$, Mann Whitney test. UT: untreated control cells. 


\section{Figure 8}

$\mathrm{H}_{2} \mathrm{O}_{2}$ exposure led to increased expression of inflammation gene expression while co-treatment with $5 \mu \mathrm{g} / \mathrm{ml}$ Gyp reversed the effects. (A-C) mRNA levels of IL1- $\beta$, IL-6 and IL-8 in ARPE-19 cells treated with $750 \mu \mathrm{M} \mathrm{H}_{2} \mathrm{O}_{2}$ alone or with $750 \mu \mathrm{M} \mathrm{H}_{2} \mathrm{O}_{2}$ plus $5 \mu \mathrm{g} / \mathrm{ml}$ Gyp for $24 \mathrm{~h}$ were measured by qRT-PCR. The protein concentrations of IL1$\beta(D)$, IL-6 (E) and IL-8 (F) in ARPE-19 cells treated with $750 \mu \mathrm{M} \mathrm{H}_{2} \mathrm{O}_{2}$ alone or with $750 \mu \mathrm{M} \mathrm{H} \mathrm{H}_{2} \mathrm{O}_{2}$ plus $5 \mu \mathrm{g} / \mathrm{ml}$ Gyp for $24 \mathrm{~h}$ were measured by ELISA. Data were presented as mean \pm SEM $(n=9) .{ }^{*} p<0.05$, Mann Whitney test. UT: untreated control cells.

\section{Figure 9}

Exposure to Brusatol countered the protective effects of Gyp by inhibiting the NRF2 signalling pathway. (A) Exposure to Brusatol at concentrations $\geq 50 \mathrm{nM}$ significantly reduced ARPE-19 cell viability when compared to untreated controls. Data were presented as mean \pm SD $(n=9) .{ }^{*} P<0.05,{ }^{* *} P<0.01,{ }^{* * *} P<0.001$, Kruskal-Wallis test with Dunn's multiple comparisons. (B) Exposure to Brusatol (40nM) significantly reduced NRF2 protein expression in ARPE-19 cells compared to controls; ARPE-19 cells co-treated with Brusatol plus $\mathrm{H}_{2} \mathrm{O}_{2}$ plus Gyp had a significantly lower expression of NRF2 compared to cells treated with only $\mathrm{H}_{2} \mathrm{O}_{2}$ plus Gyp. Data were presented as mean \pm SEM $(n=9),{ }^{*} p<0.05$, Mann Whitney test. (C) Expression of SOD1, CAT and SESTRIN1 was markedly decreased in ARPE-19 cells exposed to $\mathrm{H}_{2} \mathrm{O}_{2}$ compared to untreated cells; exposure to $\mathrm{H}_{2} \mathrm{O}_{2}+$ Gyp resulted in a significant increase in expression of these genes. Cells exposed to Gyp $+\mathrm{H}_{2} \mathrm{O}_{2}+$ Brusatol exhibited a significant decrease in expression of the three genes when compared to cells co-treated with Gyp $+\mathrm{H}_{2} \mathrm{O}_{2}$. IL-1 $\beta$ expression was significantly increased in 
cells treated with Gyp $+\mathrm{H}_{2} \mathrm{O}_{2}+$ Brusatol when compared to cells exposed to only Gyp $+\mathrm{H}_{2} \mathrm{O}_{2}$. Data were presented as mean \pm SEM $(n=9),{ }^{*} p<0.05$, Mann Whitney test. UT: untreated control cells. B: Brusatol. 
Figure 1

A

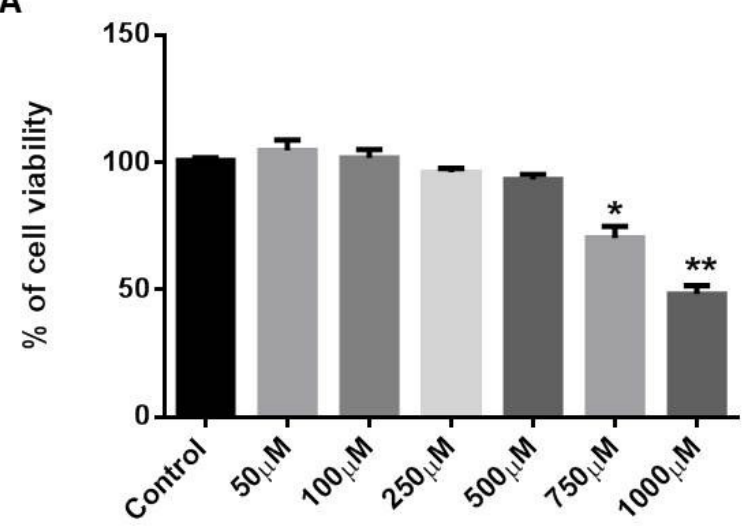

B

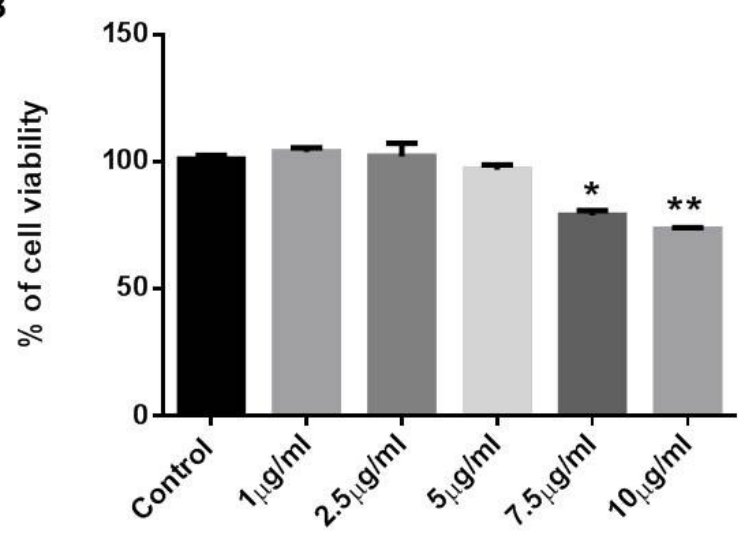

C

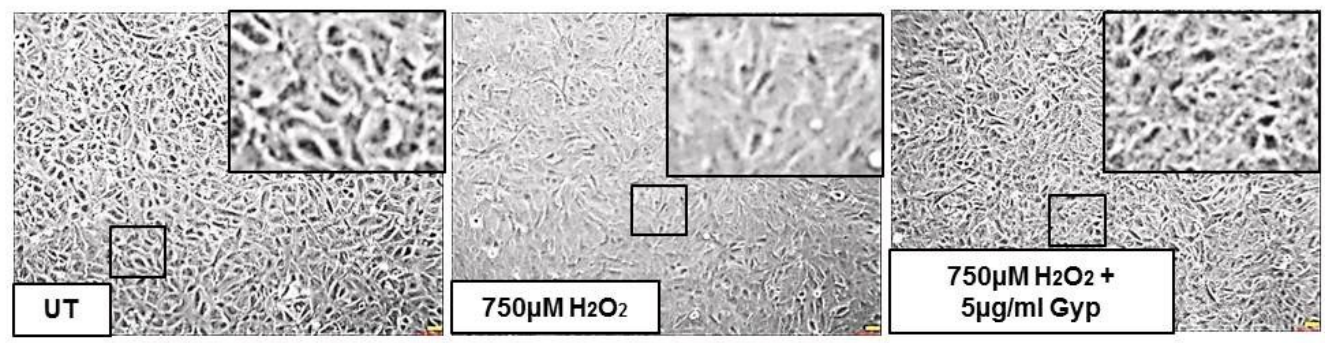

D

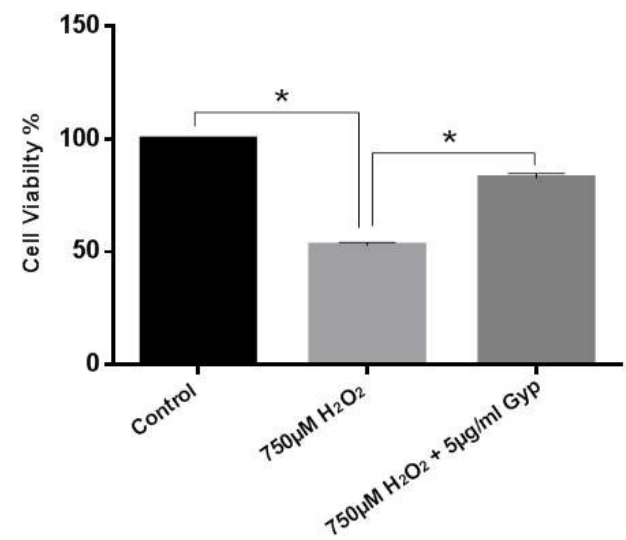


Figure 2

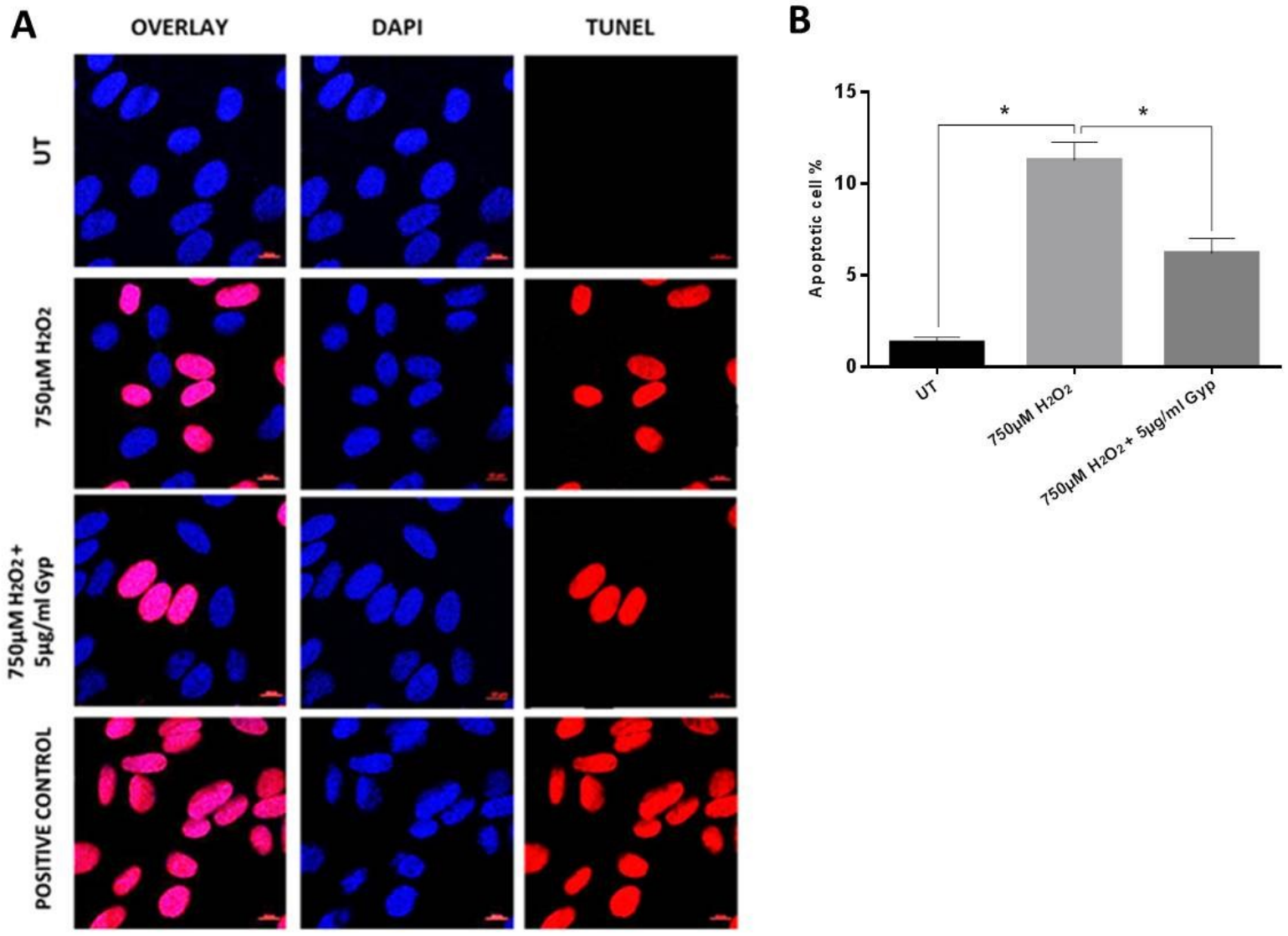

Figure 3
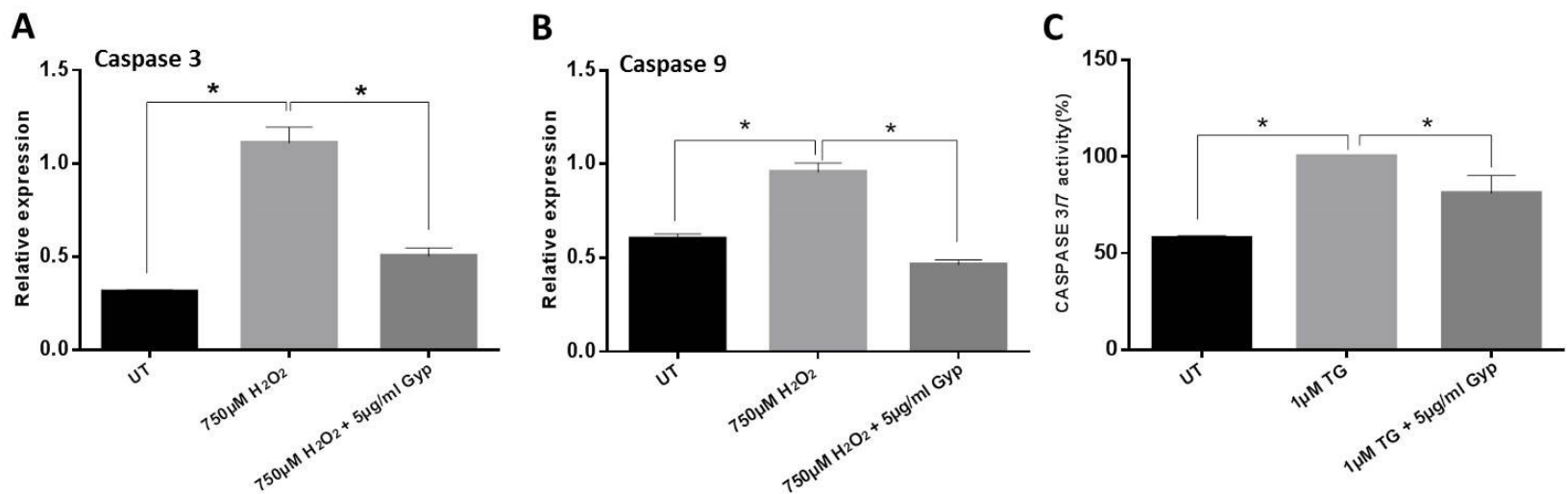
Figure 4

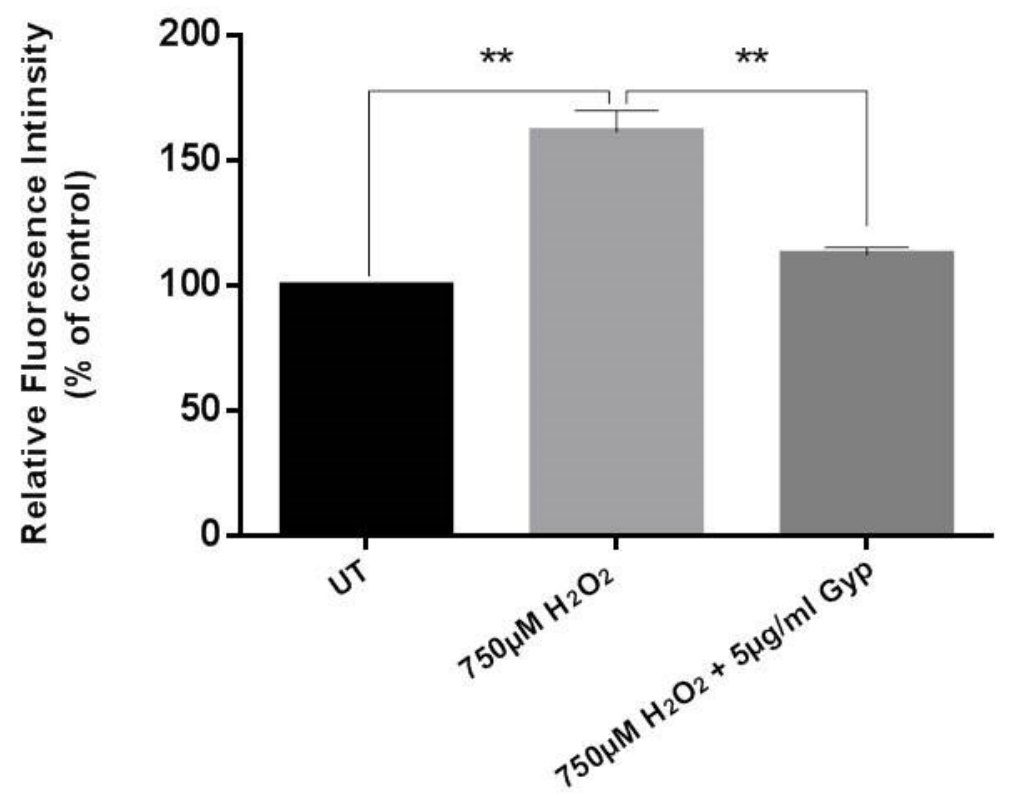

Figure 5
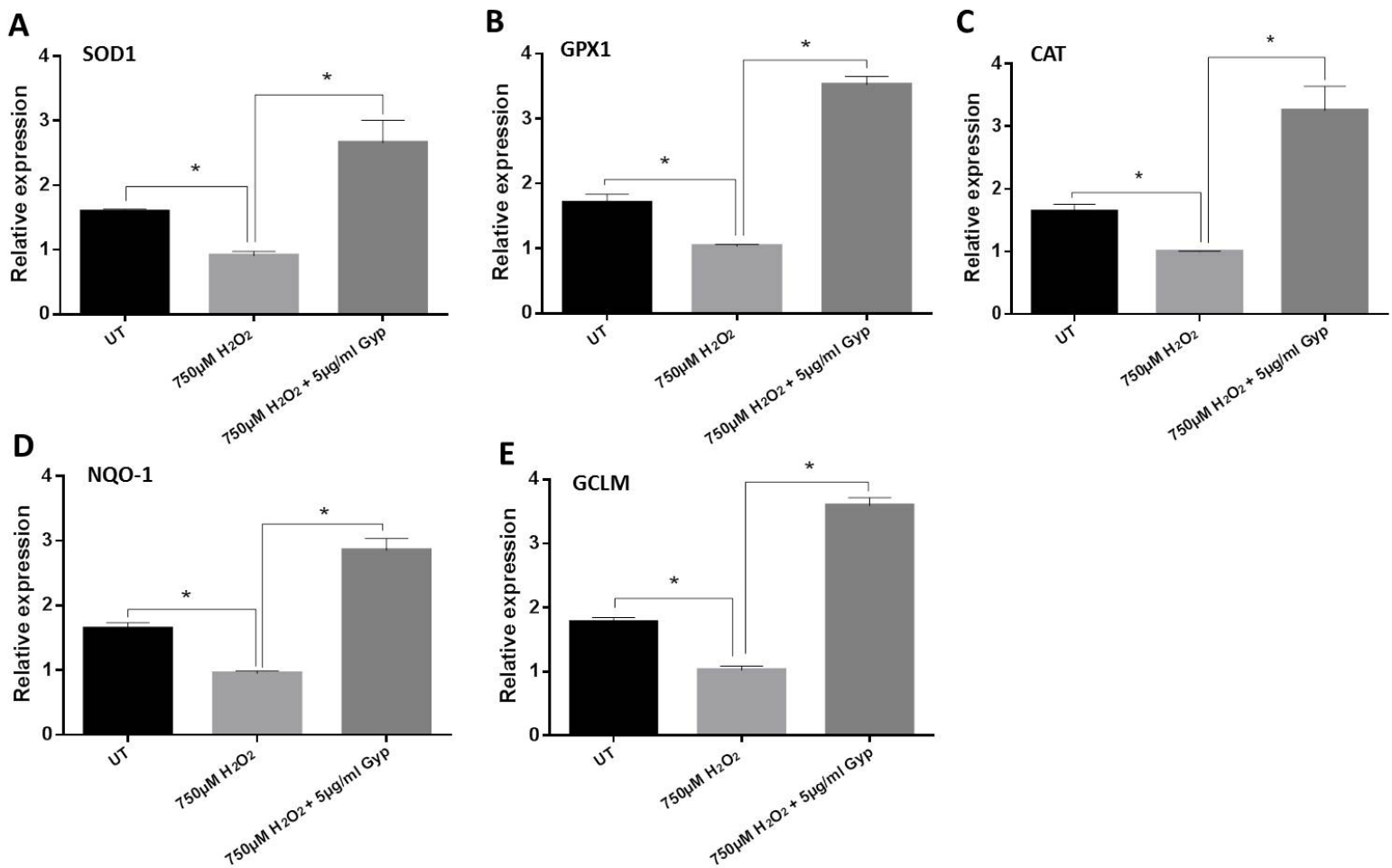
Figure 6

A
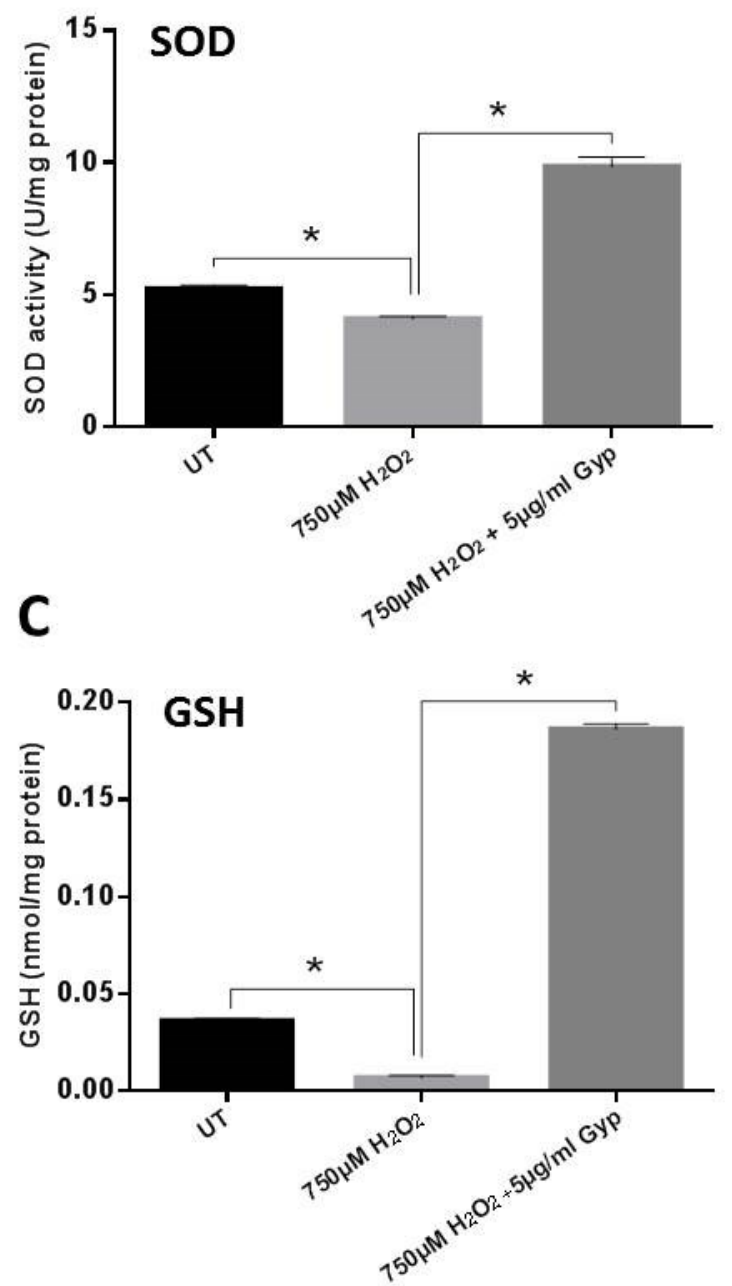

B
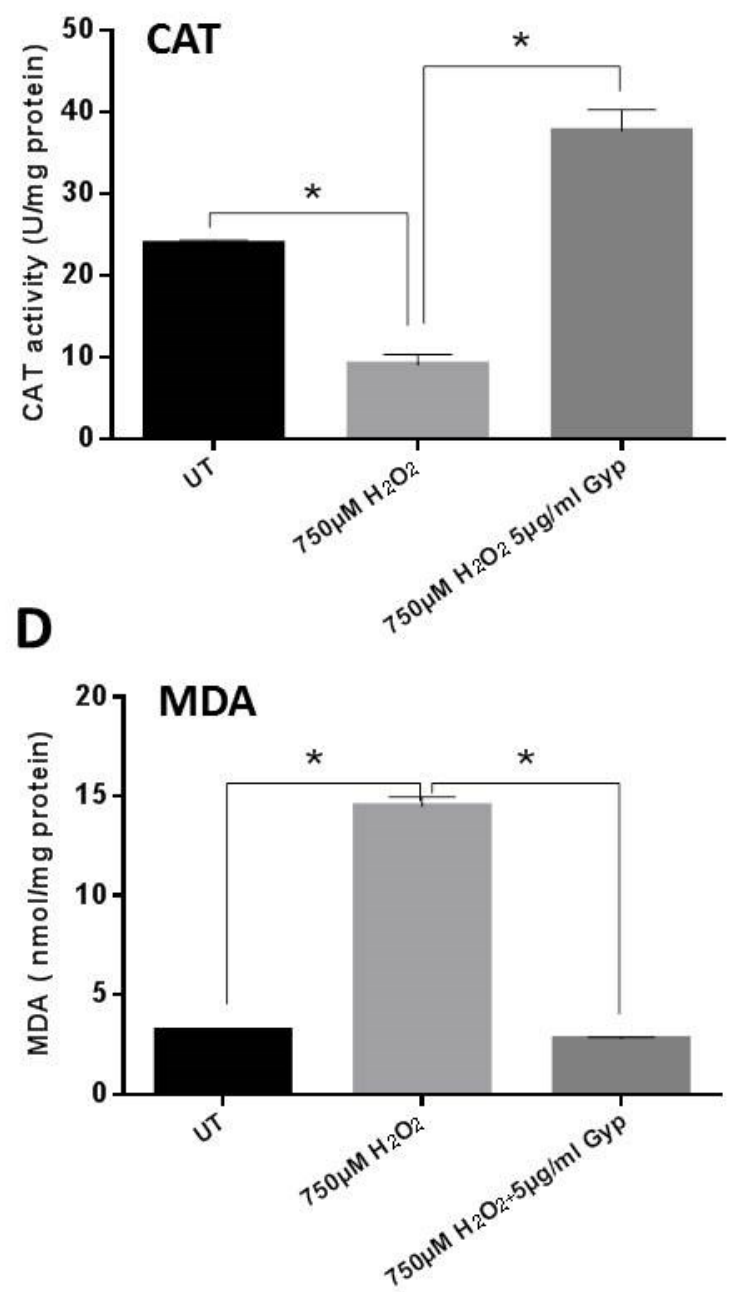


\section{Figure 7}
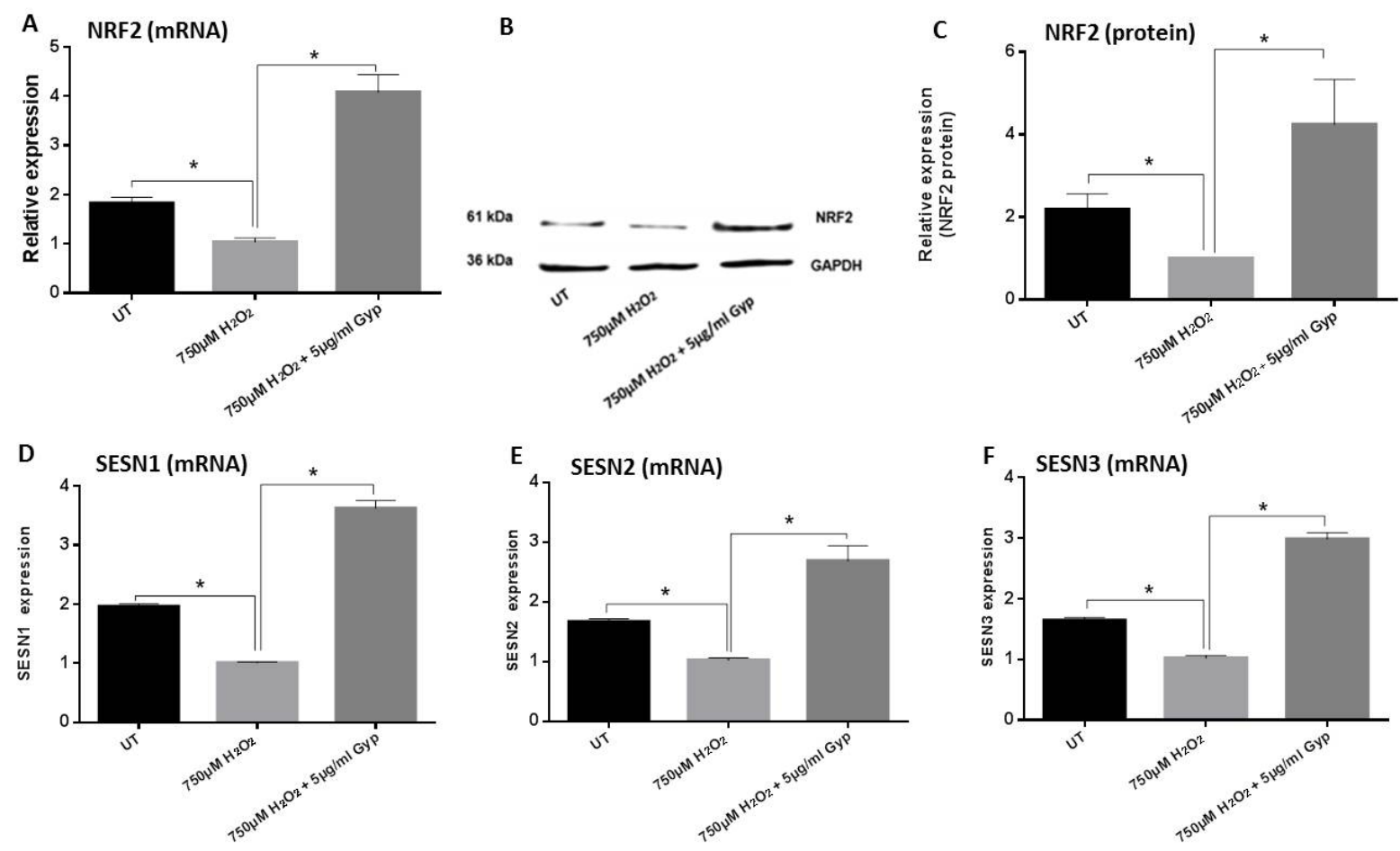

Figure 8
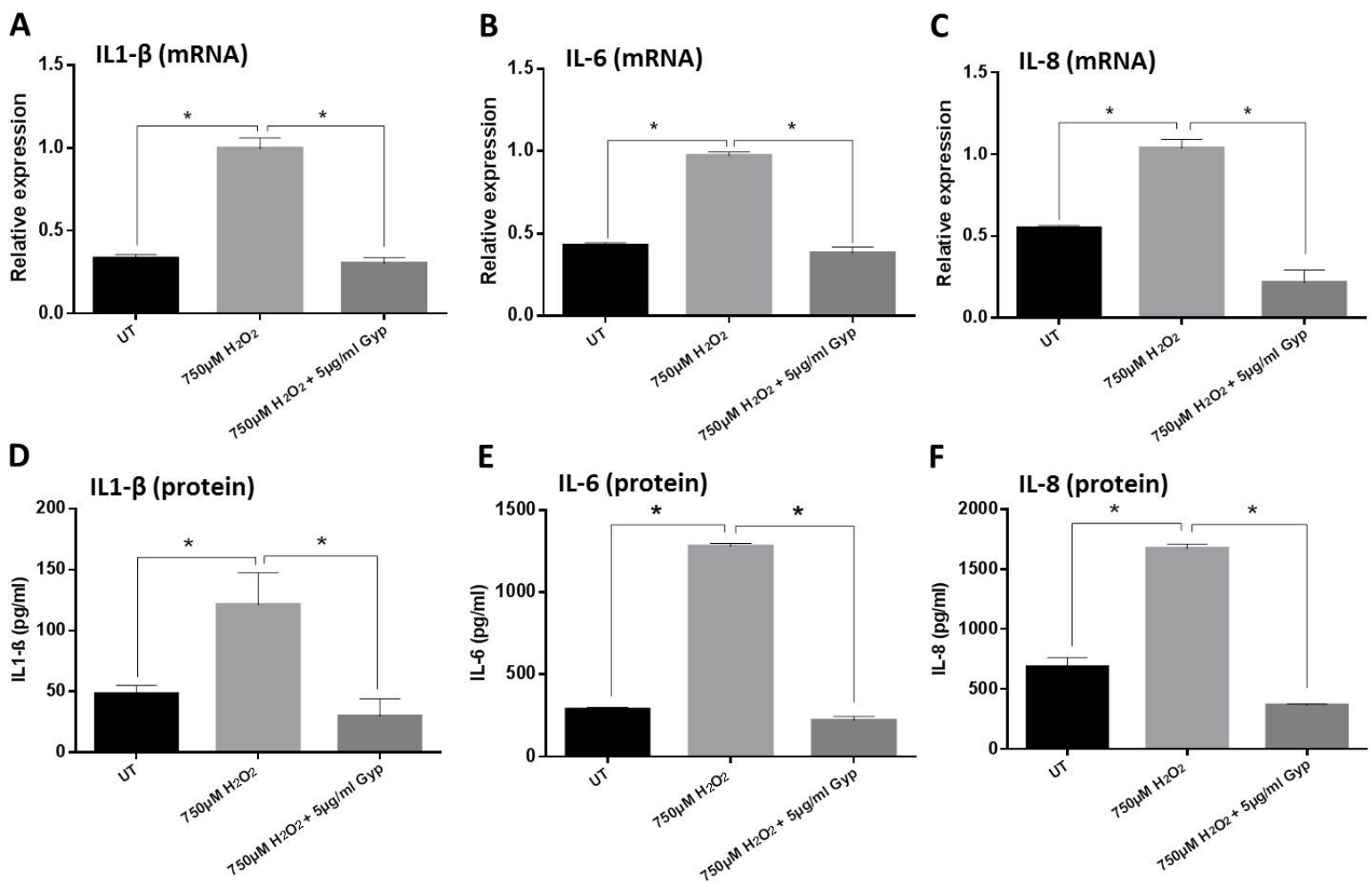
Figure 9

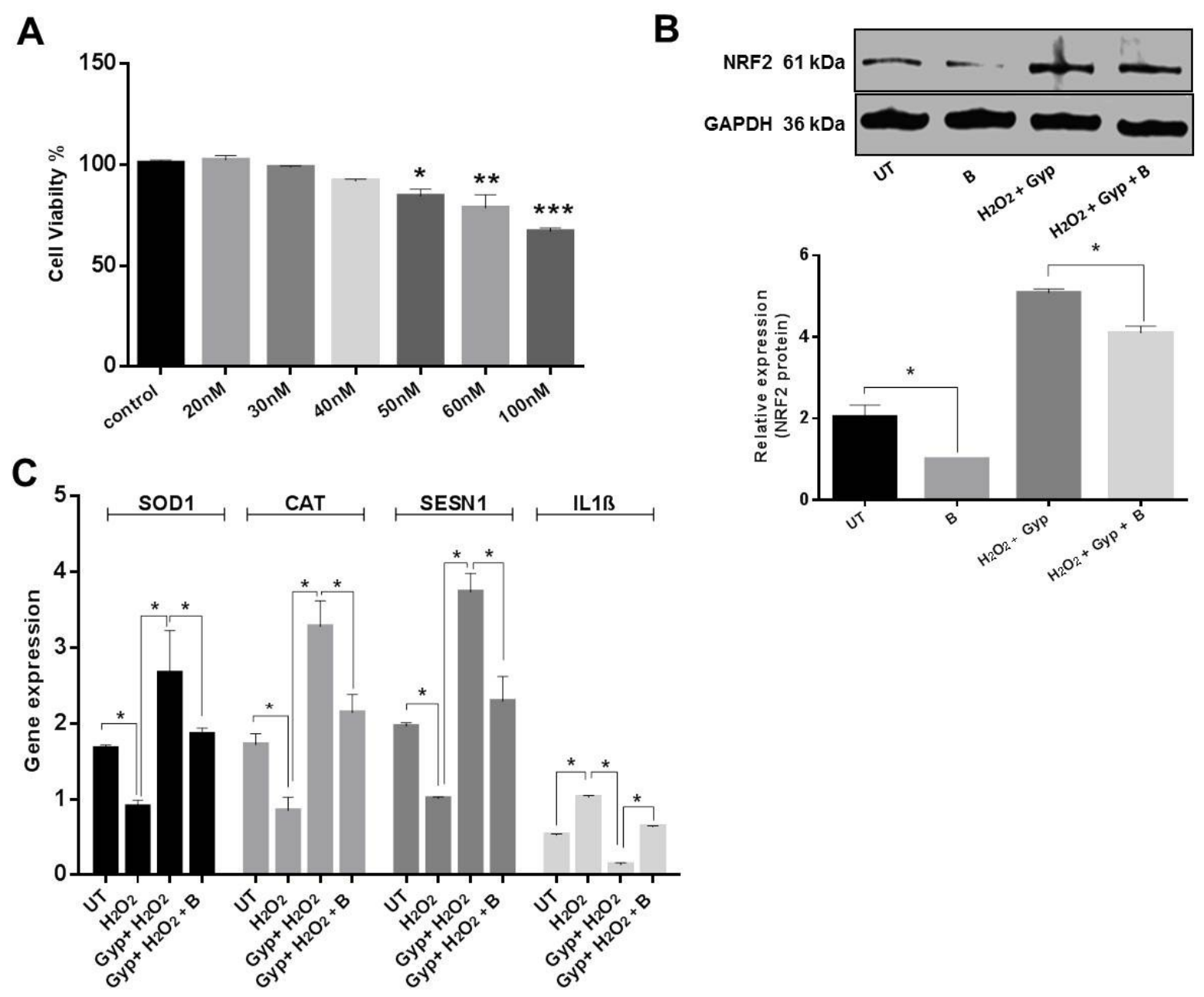




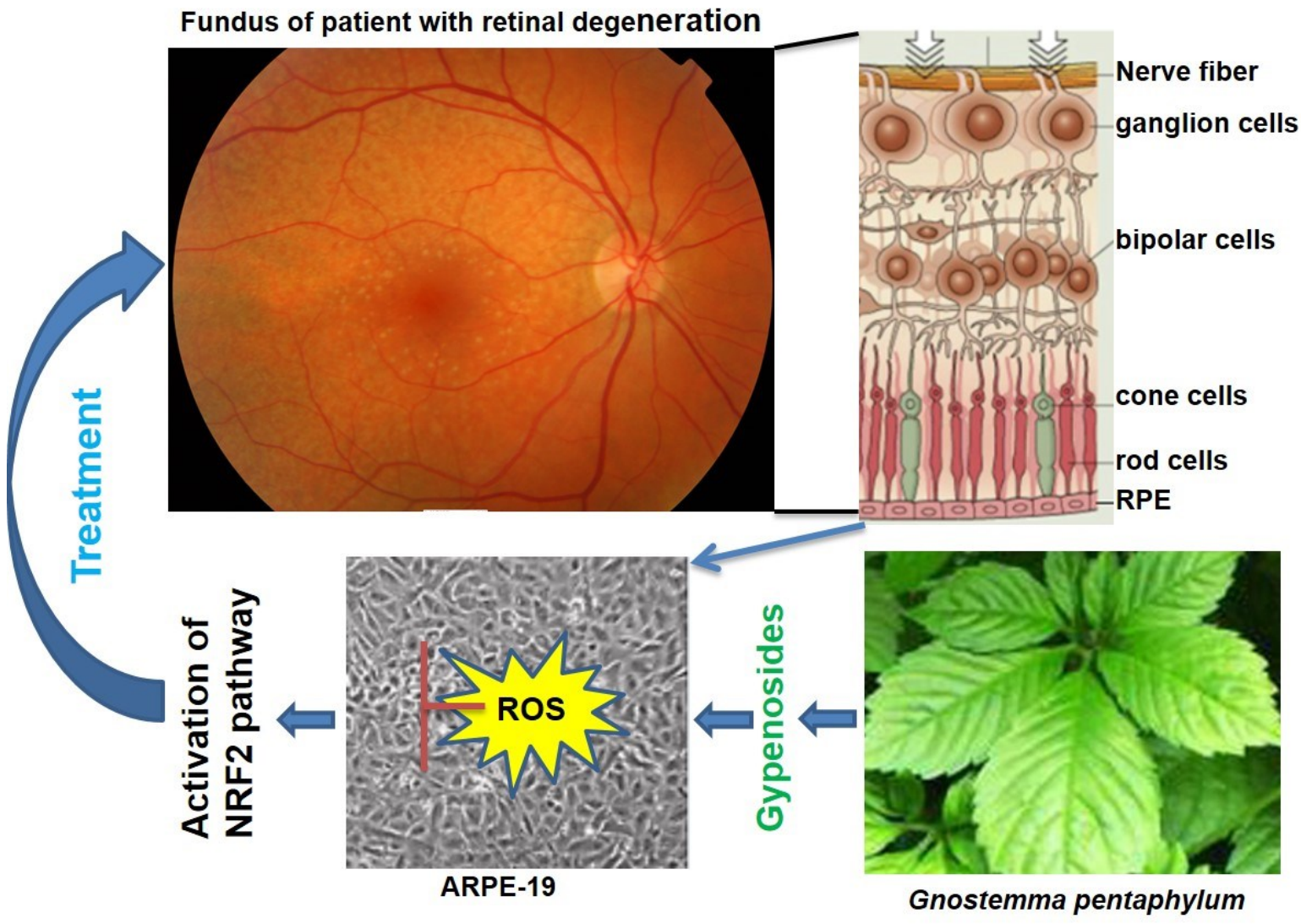

